\title{
32 DIVERTING TOILET SYSTEMS - QUALITY OF COLLECTED URINE MIXTURE COMPARED TO OTHER ORGANIC FERTILIZERS
}

\author{
Arne Backlund \\ A \& B Backlund ApS, Ordrupvej 101,DK-2920 Charlottenlund, Denmark \\ Annette Holtze \\ Storstrøm County, Tecknology \& Environment, Parkvej37, DK-4800 \\ Nykøbing $F$.
}

\begin{abstract}
Storstrøm County and A \& B Backlund ApS are cooperating in four wastewater projects running since 1998 conceming source control, diverting toilet technology and analysis of collected human urine mixture and composted human faeces. Results from one of the projects are presented in this paper. A \& B Backlund ApS is working with further four national and international projects and are planning for further projects. The projects are carried out in an Action Plan administrated by the Danish Environmental Protection Agency (EPA). Danish EPA is not responsibel for the conclusions or expressed views in the reports.

The collected user experiences in the Danish projects show that the diverting technology are accepted in a housing area, is running very well in a public place and are even highly appreciated in allotment gardens (even if further technical improvement should be made). This paper presents contents of nutrients, heavy metals, organic compounds and microorganisms found in urine mixture compared to findings in organic fertilizers used in danish agriculture. The analysed urine mixture was of high quality.

No-mixing toilets, diverting toilets, separation toilets, composting toilets, biological toilets, waterless urinals, wastewater treatment, ecological engineering, ecological sanitation, human urine, human faeces, nutrients, heavy metals, pathogens, compost, sludge, manure, anaerobicly processed biomass
\end{abstract}

\section{INVOLMEMENT IN DANISH PROJECTS}

The Danish EPA is administrating an action plan with ecological recycling of nutrients in wastewater from cities to agriculture and ecological solutions for rural areas.

Storstrøm County and A \& B Backlund ApS are co-operating in four projects in the action plan.

Storstrøm County is a "green" county and has already for many years been involved in many activities among others in ecological sanitation systems for rural areas (3). Storstrøm county has also interest in international co-operation in projects and is represented by Ame Backlund, A \& B Backlund ApS at the conference, ECO-TECH. Three Storstrøm County projects are dealing with diverting sanitary technology systems and systems have been established in the county: 1) Composting of human faeces collected from a diverting double flushing toilet 2) Collecting of human urine from double flushing diverting toilets and a waterless urinal (13) 3) 
Vacuum toilet systems for local collection of human faeces and central anaerobic digestion treatment.

A \& B Backlund ApS are working with further four diverting toilet system projects in the action plan 1) R \& D regarding diverting sanitary systems, waterless urinals and separation of faeces from flushwater (4). 2) Ecological handling of human urine and human faeces and greywater in allotment gardens by using no mixing toilets without flush and willow evaporation beds without discharge for greywater (6). 3) R \& D of composting in compost toilet systems. 4) Fertilising of willows with urine mixture from diverting toilets (7). Two further composting projects are expected to be carried out $2002-2003$.

\section{REFLECTIONS IN A MODERN RISK SOCIETY}

Flushing away human nutrients as waste in a modern risk society is a risk flushing away, wasting a sustainable future. We could stop operating in a disposal paradigm as a reflex to hygienic problems approximately 150 years ago and start to reflect. The history of utilising human rest products goes thousands of years back in history. Ecological engineering and ecological sanitation is a road to develop safe sanitation systems suitable for designing high quality fertiliser from human rest products. Wastewater and sludge are risks inherited from a disposal paradigm with disposal technology and are not automatically suitable for recirculation to agriculture. We can not solve the problems with the same sort of thinking that created the problems. Flushing and dilution is no solution to pollution. Modern risks are social constructions to be reflected and not handled by reflex. Human urine as waste or a wasted resource that is one of the questions (10), (12), (17).

\section{ECOLOGICAL SANITATION - HUMAN URINE AND FAECES}

Ecological sanitation must among others be safe and secure recycling of human nutrients of high quality back to agriculture.

Table 1 shows that even if human urine is only less than $1,5 \%$ of the volume of household wastewater it contains most of the nutrients and only a very small part of the heavy metals.

Table 1 Distribution of mass, nutrients and heavy metals in domestic wastewater (19)

\begin{tabular}{|l|c|c|l|l|}
\hline \multicolumn{1}{|c|}{ Parameter } & Unit & Urine & Faeces & Greywater \\
\hline Mass & $\mathrm{kg} /$ year & 550 & 40 & 40000 \\
\hline Nitrogen & $\%$ & 80 & 11 & 9 \\
\hline Phosphorous & $\%$ & 55 & 28 & 17 \\
\hline Potassium & $\%$ & 60 & 16 & 24 \\
\hline Copper & $\%$ & 1.407 & 15.290 & 83.303 \\
\hline Chromium & $\%$ & 0.333 & 0.657 & 99.010 \\
\hline Nickel & $\%$ & 0.347 & 3.602 & 96.051 \\
\hline Zinc & $\%$ & 0.099 & 24.397 & 75.504 \\
\hline Lead & $\%$ & 0.063 & 0.662 & 99.275 \\
\hline Cadmium & $\%$ & 0.579 & 5.355 & 94.066 \\
\hline Mercury & $\%$ & 3.030 & 46.060 & 50.910 \\
\hline
\end{tabular}


Table 2 shows the contents of heavy metals related to Danish limit values. Especially the values for urine are very much under the limit values.

Table 2 Heavy metals in human urine and human faeces in relation to dry material (DM) and compared to Danish limit values (13), (19)

\begin{tabular}{|l|c|r|r|c|}
\hline \multirow{2}{*}{ Parameter } & Unit & Urine & Faeces & Limit values \\
\hline Copper & $\mathrm{mg} / \mathrm{kg} \mathrm{DM}$ & 1.690 & 22.333 & 1000 \\
\hline Chromium & $\mathrm{mg} / \mathrm{kg} \mathrm{DM}$ & 0.469 & 0.406 & 100 \\
\hline Nickel & $\mathrm{mg} / \mathrm{kg} \mathrm{DM}$ & 0.119 & 1.500 & 30 \\
\hline Zinc & $\mathrm{mg} / \mathrm{kg} \mathrm{DM}$ & 0.731 & 219.000 & 4000 \\
\hline Lead & $\mathrm{mg} / \mathrm{kg} \mathrm{DM}$ & 0.032 & 0.406 & 120 \\
\hline Cadmium & $\mathrm{mg} / \mathrm{kg} \mathrm{DM}$ & 0.018 & 0.206 & 0.8 \\
\hline Mercury & $\mathrm{mg} / \mathrm{kg} \mathrm{DM}$ & 0.023 & 0.422 & 0.8 \\
\hline
\end{tabular}

Human urine is only considered a potential health problem due to potential cross contamination by faecal material. Table 3 shows values for indicator bacteria's in fresh human faeces.

Table 3 Contents of indicator bacteria in human faeces (14), (15)

\begin{tabular}{|l|c|c|}
\hline Indicator bacteria & Unit & Content in faeces \\
\hline Total koliforms & $\mathrm{Cfu} / \mathrm{g}$ & $10000.000-1000000000$ \\
\hline E.ecoli & $\mathrm{Cfu} / \mathrm{g}$ & $10000000-1000000000$ \\
\hline Enterococci & $\mathrm{Cfu} / \mathrm{g}$ & $100000-1000000$ \\
\hline
\end{tabular}

\section{NO MIXING TOILETS AND WATERLESS URINALS}

Human beings with two outlets for urine and faeces are constructing toilets with only one inlet. Mixing is the answer to an often forgotten question. Why mixing? No mixing toilets and waterless urinals are possibilities to continue where our natural physical process ends with reflected handling and processing of our human restproducts. We must consciously design restproducts.

\section{EXPERIENCES WITH AND FUNCTIONING OF SYSTEMS}

\section{"Museumsgården" (Møn)}

Museumsgården is a museum open in the summer season. The museum collects human urine mixture in two 5-m3 tanks from visitors using four flushing diverting toilets "WM-DS" and one waterless urinal. The typicle visitor is a one-time visitor. The system installed in 1998 has been functioning very well and due to very good information there has been no problems with the use of the system (13).

\section{Allotment gardens}

89 diverting toilets, eight different models, without water flush and typically $25-1$ containers for collecting urine were installed in 1999 - 2000. Specified user experiences with functioning of the different parts of the systems and handling of human urine and human faeces were collected from 81 of the installations. The families has agreed to join the project, 
has chosen and installed the diverting toilet them selves and further on also handled human urine and faeces them selves. All of the interviewed families were either satisfied or very satisfied with the systems (6).

\section{Hyldespjældet and Svanholm}

9 diverting flushing toilets "WM-DS" were installed in 1998 in 9 flats with totally 12 grown ups and 10 children in Hyldespjældet and two toilets "WM-DS" were in the same year installed at the organic farming estate "Svanholm". The toilets have been accepted but the users would like further development of the water flush for urine, the water lock and the user friendliness for the children (1), (16), (18).

\section{CONTENTS IN COLLECTED AND STORED HUMANE URINE SOLUTION COMPARED TO OTHER ORGANIC FERTILIZERS}

Table 4 shows electrical conductivity and content of nutrients in different urine mixtures.

Table 4 Electrical conductivity and content of nutrients in EPA projects (6), (11), (13), (16)

\begin{tabular}{|l|l|l|r|r|r|r|c|}
\hline \multicolumn{1}{|c|}{ Parameter } & Unit & Møn T0 & Møn T4 & Møn T6 & Hyldes. & Svanh. & Allotm. \\
\hline El.conductivity & $\mathrm{ms} / \mathrm{m}$ & 1500 & 1500 & 1400 & 1400 & 1730 & 3000 \\
\hline Nitrogen & $\mathrm{mg} / \mathrm{l}$ & 1800 & 1500 & 1600 & 2000 & 2500 & 5400 \\
\hline Phosphorous & $\mathrm{mg} / \mathrm{l}$ & 74 & 77 & 68 & 100 & 170 & 360 \\
\hline Potassium & $\mathrm{mg} / \mathrm{l}$ & 680 & 670 & 590 & 430 & 1200 & 1100 \\
\hline Ammonium & $\mathrm{mg} / \mathrm{l}$ & 1800 & 1500 & 1600 & 1500 & 2200 & 5100 \\
\hline Calcium & $\mathrm{mg} / \mathrm{l}$ & 36.6 & & & 20,4 & & 9.67 \\
\hline Magnesium & $\mathrm{mg} / \mathrm{l}$ & $<1.80$ & & & $<1.80$ & 0.2 & $<1.8$ \\
\hline Sodium & $\mathrm{mg} / \mathrm{l}$ & 616 & & & 756 & & 1700 \\
\hline
\end{tabular}

$\mathrm{T}(\mathrm{x})$ : Month of storage without further supply

In table 5 the content of nutrients in "Møn" is compared to contents in other organic fertilisers. It is obvious that especially the concentration of $\mathrm{P}$ is very low in "Møn"

Table 5 Contents of nutrients in collected urine mixture "Mon" compared to other organic fertilisers(11), (13), (19)

\begin{tabular}{|l|c|r|r|r|r|r|r|}
\hline \multicolumn{1}{|c|}{ Parameter } & Unit & Urine & Møn, T0 & $\begin{array}{c}\text { Waste water } \\
\text { Sludge }\end{array}$ & Compost & $\begin{array}{c}\text { Pig } \\
\text { manure }\end{array}$ & $\begin{array}{c}\text { Cattle } \\
\text { manure }\end{array}$ \\
\hline DM-percent. & \multicolumn{1}{c|}{$\%$} & 3.98 & 0.3384 & 13.648 & 66.434 & 6.739 & 11.899 \\
\hline Nitrogen & $\mathrm{mg} / \mathrm{kg} \mathrm{Mass}$ & 7300 & 1800 & 5897 & 5944 & 9058 & 7377 \\
\hline Nitrogen & $\mathrm{mg} / \mathrm{kgdM}$ & 130000 & 532544 & 43500 & 9000 & 127000 & 55000 \\
\hline Phosphorous & $\mathrm{mg} / \mathrm{kg} \mathrm{Mass}$ & 670 & 74 & 4297 & 1399 & 1812 & 857 \\
\hline Phosphorous & $\mathrm{mg} / \mathrm{kgeDM}$ & 16700 & 21893 & 30300 & 2000 & 28000 & 11000 \\
\hline Potassium & $\mathrm{mg} / \mathrm{kg} \mathrm{Mass}$ & 2000 & 680 & 421 & 2448 & 3261 & 6188 \\
\hline Potassium & $\mathrm{mg} / \mathrm{kg} \mathrm{DM}$ & 35000 & 201183 & 3600 & 3500 & 72000 & 50000 \\
\hline
\end{tabular}

Table 6 shows contents of heavy metal compared and related to Danish limit values on the basis of dry material. The contents in "Møn" are by far the lowest. 
Table 6.Contents of heavy metals in organic fertilisers compared to "Mon" and Danish limit values (6), (11), (13)

\begin{tabular}{|l|c|c|c|c|c|c|c|}
\hline Parameter & Unit & $\begin{array}{c}\text { WW } \\
\text { Sludge }\end{array}$ & $\begin{array}{c}\text { Househ. } \\
\text { Compost }\end{array}$ & $\begin{array}{c}\text { Pig } \\
\text { manure }\end{array}$ & $\begin{array}{c}\text { Cattle } \\
\text { Manure }\end{array}$ & MønsT0 & $\begin{array}{c}\text { Danish } \\
\text { Limit v. }\end{array}$ \\
\hline Cadmium & $\mathrm{Mg} / \mathrm{kgsDM}$ & 2.0 & 0.3 & 0.5 & 0.6 & $>0.0118$ & 0.8 \\
\hline Mercury & $\mathrm{Mg} / \mathrm{kgsDM}$ & 1.4 & 0.1 & $<0.1$ & $<0.1$ & - & 0.8 \\
\hline Lead & $\mathrm{Mg} / \mathrm{kg} \mathrm{DM}$ & 71 & 32 & 3 & 4 & 0.49 & 120 \\
\hline Nickel & $\mathrm{Mg} / \mathrm{kg} \mathrm{DM}$ & 23 & 9 & 14 & 8 & 1.25 & 30 \\
\hline Chromium & $\mathrm{Mg} / \mathrm{kg} \mathrm{DM}$ & 32 & 11 & 10 & 3 & 0.49 & 100 \\
\hline Zinc & $\mathrm{Mg} / \mathrm{kgSDM}$ & 760 & 150 & 1.500 & 150 & 45.86 & 4000 \\
\hline Copper & $\mathrm{Mg} / \mathrm{kgsDM}$ & 262 & 50 & 630 & 65 & 3.05 & 1000 \\
\hline
\end{tabular}

In table 7 the levels are compared on the basis of $\mathrm{N}$ which would be the interesting parameter Using urine mixture as a fertiliser. The values for urine mixture are far below the values for other fertilisers.

Table 7. Heavy metals in urine mixture "Mons" compared to other organic fertilisers.

Concentrations in $\mathrm{mg} / \mathrm{kg} \mathrm{N}$. (11), (13)

\begin{tabular}{|l|c|c|c|c|c|c|}
\hline \multicolumn{1}{|c|}{ Parameter } & Unit & MønsT0 & $\begin{array}{c}\text { WW } \\
\text { Sludge }\end{array}$ & $\begin{array}{c}\text { Housh. } \\
\text { compost }\end{array}$ & $\begin{array}{c}\text { Pig } \\
\text { Manure }\end{array}$ & $\begin{array}{c}\text { Cattle } \\
\text { Manure }\end{array}$ \\
\hline Cadmium & $\mathrm{mg} / \mathrm{kg} \mathrm{N}$ & $<0.02$ & 32.9 & 35 & 3.6 & 8.5 \\
\hline Chromium & $\mathrm{mg} / \mathrm{kgsN}$ & $<0.91$ & 929 & 1118 & 72 & 45 \\
\hline Copper & $\mathrm{mg} / \mathrm{kgsN}$ & 5.72 & 17857 & 5588 & 2640 & 1097 \\
\hline Mercury & $\mathrm{mg} / \mathrm{kg} \mathrm{N}$ & & 31.4 & 12 & & \\
\hline Nickel & $\mathrm{mg} / \mathrm{kg} \mathrm{N}$ & 2.34 & 571 & 1000 & 96 & 116 \\
\hline Zinc & $\mathrm{mg} / \mathrm{kg} \mathrm{N}$ & 86.11 & 7000 & 16471 & 6120 & 1742 \\
\hline Lead & $\mathrm{mg} / \mathrm{kg} \mathrm{N}$ & 0.92 & & & 24 & 58 \\
\hline
\end{tabular}

Table 8 shows contents of PAH, DEHP, NPE and LAS found in different urine mixtures.

Table 8. Contents of PAH, DEHP, NPE and LAS, in human urine mixtures in EPA projects (11), (13)

\begin{tabular}{|l|l|c|c|c|c|c|c|}
\hline Parameter & Unit & MønsT0 & MønsT4 & $\begin{array}{l}\text { Møn } \\
\text { T6 }\end{array}$ & $\begin{array}{l}\text { Hyldesp. } \\
\text { T0 }\end{array}$ & $\begin{array}{l}\text { Svan- } \\
\text { holm }\end{array}$ & $\begin{array}{l}\text { Allotm.g. } \\
\text { T0 }\end{array}$ \\
\hline PAH & ug/l & 0.000 & 0.069 & 0.34 & 0.094 & $<10$ & 0.85 \\
\hline DEHP & ug/l & 2.4 & 20 & 5.4 & 3.0 & 29.0 & 20 \\
\hline NPE & ug/l & 0.0 & 9.8 & 11 & 0.0 & $<15$ & 27 \\
\hline LAS & ug/l & $<20$ & $<20$ & $<20$ & $<20$ & $<0.030$ & $<0.02$ \\
\hline
\end{tabular}

In table 9 contents are compared and it is shown that urine mixture is far below sludge and compost and at the same level as manure. 
KALMAR ECO-TECH'01

Leachate and Wastewater Treatment with High-Tech and Natural systems

KALMAR, SWEDEN, November 26-28, 2001

Table 9. Contents of LAS, PAH, NPE and DEHP in "Mon" compared to contents in sludge, compost and manure. Concentrations in $\mathrm{mg} / \mathrm{kg} \mathrm{N}(6)$, (13)

\begin{tabular}{|l|l|c|c|c|c|c|}
\hline \multicolumn{1}{|c|}{ Parameter } & \multicolumn{1}{c|}{ Unit } & $\begin{array}{c}\text { Møn } \\
\text { T0-T6 }\end{array}$ & $\begin{array}{c}\text { WW } \\
\text { Sludge }\end{array}$ & $\begin{array}{c}\text { HH } \\
\text { Compost }\end{array}$ & $\begin{array}{c}\text { Pig } \\
\text { Manure }\end{array}$ & $\begin{array}{c}\text { Cattle } \\
\text { Manure }\end{array}$ \\
\hline LAS & $\mathrm{mg} / \mathrm{kg} \mathrm{N}$ & $<12.5$ & 61429 & 2353 & & \\
\hline PAH & $\mathrm{mg} / \mathrm{kg} \mathrm{N}$ & $0-0.2$ & 143 & 59 & 0,16 & 0.32 \\
\hline NPE & $\mathrm{mg} / \mathrm{kg} \mathrm{N}$ & $0-6.9$ & 357 & 59 & 8 & 16 \\
\hline DEHP & $\mathrm{mg} / \mathrm{kg} \mathrm{N}$ & $1.3-13.3$ & 857 & 1176 & & \\
\hline
\end{tabular}

In table 10 contents of microorganisms in urine mixtures are compared

Table 10. Contents of microorganisms in urine mixture "Mons' and other urine mixtures (6), (13)

\begin{tabular}{|c|c|c|c|c|c|}
\hline Parameter & Unit & $\begin{array}{c}\text { Time } \\
\text { Tmonth }\end{array}$ & Møn & Hyldespj. & $\begin{array}{l}\text { Allotment } \\
\text { garden }\end{array}$ \\
\hline \multicolumn{6}{|l|}{$\begin{array}{l}\text { Bacterial } \\
\text { Indicators }\end{array}$} \\
\hline $\begin{array}{l}\text { Kimtal } \\
37 \text { grader }\end{array}$ & $\mathrm{cfu} / \mathrm{ml}$ & $\begin{array}{l}\text { T0 } \\
\text { T1 } \\
\text { T2 } \\
\text { T3 } \\
\text { T4 } \\
\text { T5 } \\
\text { T6 }\end{array}$ & $\begin{array}{r}16000 \\
900 \\
500 \\
700 \\
500 \\
600 \\
670\end{array}$ & $\begin{array}{r}9700 \\
1000 \\
100 \\
<100 \\
<100 \\
500 \\
3100\end{array}$ & $\begin{array}{r}470000 \\
100 \\
<100\end{array}$ \\
\hline $\begin{array}{l}\text { Termotol. } \\
\text { Coliforms }\end{array}$ & $\mathrm{cfu} / 100 \mathrm{ml}(\mathrm{mg})$ & $\begin{array}{l}\text { T0 } \\
\text { T1 }\end{array}$ & $<2$ & & $\begin{array}{l}<1 \\
<1\end{array}$ \\
\hline E.coli & $\mathrm{cfu} / 100 \mathrm{ml}$ & $\begin{array}{l}\text { T0 } \\
\text { T1 } \\
\text { T2 }\end{array}$ & $\begin{array}{r}<1 \\
<10 \\
<10\end{array}$ & $\begin{array}{l}<10 \\
<10 \\
<10\end{array}$ & \\
\hline Enterococci & $\mathrm{cfu} / 100 \mathrm{ml}$ & $\begin{array}{l}\text { T0 } \\
\text { T1 } \\
\text { T2 } \\
\text { T3 } \\
\text { T4 } \\
\text { T5 } \\
\text { T6 } \\
\end{array}$ & $\begin{array}{r}1800 \\
350 \\
<10 \\
<1 \\
<10 \\
10 \\
50 \\
\end{array}$ & $\begin{array}{r}3300 \\
320 \\
340 \\
4 \\
<10 \\
10 \\
<10 \\
\end{array}$ & $\begin{array}{r}1500000 \\
40 \\
<10\end{array}$ \\
\hline \multicolumn{6}{|l|}{$\begin{array}{l}\text { Infect. } \\
\text { Bacteria }\end{array}$} \\
\hline $\begin{array}{l}\text { Campylo- } \\
\text { bacter }\end{array}$ & $\mathrm{c} / 10 \mathrm{~g}(\mathrm{ml})$ & T0-T2 & Neg. & neg. & neg.(T0-T1) \\
\hline Salmonella & $\mathrm{c} / 10 \mathrm{~g}(\mathrm{ml})$ & T0-T2 & Neg. & neg. & i.p. (T0-T1) \\
\hline \multicolumn{6}{|l|}{ Parasites } \\
\hline $\begin{array}{l}\text { Cryptosp. } \\
\text { Parvum }\end{array}$ & $\begin{array}{l}\text { Positive/ } \\
\text { Negative } \\
\text { (antal pr. ml.) }\end{array}$ & $\begin{array}{l}\text { T3 } \\
\text { T4 } \\
\text { T5 } \\
\text { T6 } \\
\end{array}$ & $\begin{array}{l}\text { Pos.(6) } \\
\text { Pos.(11) } \\
\text { Pos.(11) } \\
\text { Pos.(5) }\end{array}$ & $\begin{array}{l}\text { pos. } \\
\text { pos. } \\
\text { pos. }\end{array}$ & neg. (T1) \\
\hline Giardia & pos./neg. & & Neg. & neg. & neg. \\
\hline Duodenalis & pos./neg. & & Neg. & neg. & neg. \\
\hline $\begin{array}{l}\text { Other ind. } \\
\text { Parasites }\end{array}$ & pos./neg. & & Neg. & neg. & neg. \\
\hline
\end{tabular}


In table 11 contents of microorganisms in "Møn" are compared to contents in manure, sludge and treated biomass. It is shown that contents in "Møn" was very much lower.

Table 11. Contents of microorganisms in "Mons' compared to manure, sludge and treated biomass

(2), (8), (9), (13), (20)

\begin{tabular}{|c|c|c|c|c|c|c|}
\hline $\begin{array}{l}\text { Para- } \\
\text { meter }\end{array}$ & $\begin{array}{l}\text { Møn } \\
\text { T2 } \\
\text { (T6) }\end{array}$ & $\begin{array}{c}\text { Pig } \\
\text { Manure }\end{array}$ & $\begin{array}{c}\text { Cattle } \\
\text { Manure }\end{array}$ & $\begin{array}{c}\text { Aerobic } \\
\text { Stabilised } \\
\text { WW sludge }\end{array}$ & $\begin{array}{c}\text { Anaerobic } \\
\text { Digested } \\
\text { WW sludge }\end{array}$ & $\begin{array}{c}\text { Treated } \\
\text { biomass } \\
\text { from biogas } \\
\text { plants }\end{array}$ \\
\hline $\begin{array}{l}\text { Kimtal } \\
\mathrm{Cfu} / \mathrm{ml}\end{array}$ & $\begin{array}{l}500 \\
(670)\end{array}$ & $\begin{array}{c}340000 \\
\text { to } \\
100000\end{array}$ & $\begin{array}{c}2000000 \\
\text { to } \\
32000000\end{array}$ & & & $\begin{array}{r}70000 \\
\text { to } \\
24500000\end{array}$ \\
\hline $\begin{array}{l}\text { Entero- } \\
\text { cocci. } \\
\mathrm{Cfu} / 100 \\
\mathrm{ml}\end{array}$ & $\begin{array}{l}<10 \\
(50)\end{array}$ & $\begin{array}{c}220000 \\
\text { to } \\
43000000\end{array}$ & $\begin{array}{c}1300.000 \\
\text { to } \\
48000000\end{array}$ & $\begin{array}{l}200.000 \\
\text { to } \\
29000000\end{array}$ & $\begin{array}{l}70.000 \\
\text { to } \\
1400000\end{array}$ & $\begin{array}{l}<1000 \\
\text { to } \\
83000000\end{array}$ \\
\hline $\begin{array}{l}\text { Campyl. } \\
\text { bacter } \\
\mathrm{c} / 10 \mathrm{~g}\end{array}$ & Neg. & $\begin{array}{l}\text { Pos. In } \\
53,5 \% \text { of } \\
\text { livestocks }\end{array}$ & $\begin{array}{l}\text { pos. In } \\
50 \text { s\% of } \\
\text { livestocks }\end{array}$ & & & \\
\hline $\begin{array}{l}\text { Salmo- } \\
\text { nella } \\
\mathrm{c} / 10 \mathrm{~g}\end{array}$ & Neg. & $\begin{array}{l}\text { Up to } \\
280000\end{array}$ & $\begin{array}{l}\text { up to } \\
280000\end{array}$ & $\begin{array}{l}130 \\
\text { to } \\
5000\end{array}$ & $\begin{array}{l}20 \\
\text { to } \\
300\end{array}$ & $\begin{array}{l}\text { pos. inst out } \\
\text { of } 53 \text { sampl. }\end{array}$ \\
\hline $\begin{array}{l}\text { Gardia } \\
\mathrm{c} / \mathrm{ml}\end{array}$ & Neg. & $0-300$ & $0-100$ & & & \\
\hline $\begin{array}{l}\text { Cryptos. } \\
\text { c/ml }\end{array}$ & $\begin{array}{l}\text { Up to } \\
11\end{array}$ & $0-200$ & $0-100$ & & & \\
\hline
\end{tabular}

\section{SWEDISH RECOMENDATIONS}

In Sweden "Swedish institute for Infectious Desease Control" recomends a storage time for urine mixture for minimum 1 or 6 month depending on storage temperature and fertilized crop. For using the urine produced in the family in their own garden no storage should be necessary $(15)(16)$.

\section{CONCLUSIONS}

The analyzed urine mixture "Møn" was compared to other organic fertilizers. The results show that the quality of the urine mixture was very high. There was no sign of a high cross contamination from faeces to the urine system (13).

\section{REFERENCES}

1. Agenda Center Albertslund, Povl Markussen 2001: "Urinopsamling og -anvendelse i Hyldespjældet”. Økologisk byfornyelse og spildevandsrensning nr. 10, Miljøstyrelsen 2001 
2. Andersen, J. S., Hald, T 2001: "Risikovurdering ved anvendelse af vandingskanoner til udspredning af gylle fortyndet med vand". Miljøprojekt nr. 606, 2001. Miljøstyrelsen.

3. Ansbæk, J., Vandmiljøkontoret 1997: "Hvad er bæredygtig spildevandsrensning?" og "Eksempler på bæredygtig spildevandsrensning" Art. i TÆT P $\AA$ Nr. 19 oktober 1997. Storstrøms Amt/TEKNIK OG MILJØ

4. Backlund, A. 2001: Udvidelse af vidensgrundlaget vedrørende......(Manuscript to EPA report)

5. Backlund, A. m.fl. 1999: Spørgeskema til brug ved telefoninterviews med og besøg hos projektdeltagere i M 226-0057.

6. Backlund, A m.fl.. 2001: Økologisk håndtering af urin og fækalier i kolonihaver ved hjælp af kildesorterende toiletter. Manuscript to EPA report.

7. Backlund, A. 2001: Third individual progress report FAIR CT97-3947 "Biomass short rotation willow coppice fertilized with nutrient from municipal wastewater (BWCW).

Ed. Stig Larsson in report with the same tittle.

8. Bendixen, H.J. et al. 1995: Smittstofreduktion i biomasse. Det veterinære forsøgsprogram i biogasfællesanlæg, Bind 1: Hovedrapport 1995. Landbrugs- og Fiskeriministeriet. Veterinærdirektoratet

9. Bendixen, H.J. udateret; Hygiene Aspects Of Anaerobic Digestion Of Mixed Wastes. Requirements in Danish Biogas Plants.

10. Drangert, J.-O., Bew, J. Winblad, U. 1997: Ecological Alternatives In Sanitation. Proceedings from Sida Sanitation Workshop. Balingholm, Sweden 6 - 9 August 1997. Publications on Water resources: No 9. Sida Swedish International development Cooperation Agency. Department for Natural Resources and the Environment. Stockholm. Sweden.

11. Eilersen, A.M., Magid J., Tjell J.C. 1998: Genanvendelse af affald på jord s. 493 - $510 \mathrm{i}$ "Affaldsteknologi". Ed. T.H. Christensen. Teknisk forlag. København.

12. Esrey, S.A., Gough, J., Rapaport, D., Sawyer, R., Simpson-Hébert, M., Vargas, J., Winblad, U. 1998: Ecological Sanitation. Sida. Swedish International Development Cooperation Agency. Stockholm. Sweden.

13. Holtze, A., Backlund, A.: Opsamling af urinblanding fra kildesorterende toiletter og et vandfrit urinal på Museumsgården. Manuscript to EPA report.

14. Höglund, C. 2001: Evaluation of microbial health risks associated with the reuse of source-separated human urine. Royal Institute of Technology (KTH). Swedish Institute for Infectious Disease Control (SMI). Department of Water and Environmental Microbiology. Stockholm. Sverige.

15. Jönsson, H., Vinnerås, B., Höglund, C., Stenström, T. A., Dalhammar, G., Kirchmann H. 2000: Kälsorterad humanurin i kretslopp. VA-FORSK RAPPORT 1/2000, Stockholm, Sverige.

16. Kolby, E., Jansen J.L.2001: "Udnyttelse af næringssalte i urin på Svanholm gods". Økologisk byfornyelse og spildevandsrensning nr. 4. Miljøstyrelsen 2001

17. Lange, J., Otterpohl, R. 1997: Abwasser - Handbuch zu einer zukunftsfähigen Wasserwirtschaft. Donaueschingen-Pfohren. Tyskland.

18. Rex, Tue 2000: Et casestudie af urinopsamling og - udbringelse i Hyldespjældet. Institut for Planlægning. DTU.

19. Vinnerås,B. 2001: Faecal separation and urine diversion for nutrient management of household biogradable waste and wastewater. Swedish University of Agricultural Sciences. Department of Agricultural Engineering. Report 244.

20. VKI - Vandkvalitetsinstituttet 1997: "Hygiejniske aspekter ved behandling og genanvendelse af organisk affald". Miljøprojekt nr. 351. Miljøstyrelsen. 